Ключевые слова: эффективное обучение, иноязычная коммуникативная компетентность, коммуникативный подход, психолого-педагогические условия, ситуативный метод.

LOBACHUK INNA. Psychological and pedagogical conditions of effective professionally oriented education of foreign language teaching of master students.

The article deals with the psychological and pedagogical conditions that promote the effective English language teaching of students in the system of professional training, analyzes contemporary approaches, communicative and situational methods of English language teaching. It is proved that providing of the corresponding psychological and pedagogical conditions, allows to achieve productive results in educational activity on development of foreign language communicative competence of masters, to identify ways of optimization and intensification of educational process.

It is determined that effective English language training of students is conditioned by two aspects: 1) the theoretical study of specific psychological and pedagogical peculiarities of students' education and the formation on this basis of principles, the practical application of which should become a condition of successful training; 2) the choice of scientifically grounded teaching methods of the English language of undergraduate students in the system of professional training.

The essence of foreign professional competence is considered and the psychological and pedagogical conditions of development of the foreign language communicative competence of the future specialist are analyzed.

It is proved that the results of a foreign language learning are much better in the existence of students' cognitive interest and motivation based on understanding the importance of a foreign language in modern life and the possibilities of its use in professional activities. Foreign language should be an important component of the professional training of students of higher educational institutions.

It is determined that the use of different methods, principles and new information technologies in the foreign languages teaching promotes the intensification of the educational process, increasing the motivation and effectiveness of learning in general, the interest of students and undoubtedly activate the student's educational activity.

Keywords: effective learning, foreign language communicative competence, communicative approach, psychological and pedagogical conditions, situational method.

DOI: https://doi.org/10.31392/NZ-npu-142.2019.16

УДК 378[37.013+78]

Макарова Е. В., Яковенко В. Г.

\title{
ФОРМУВАННЯ ТВОРЧОЇ ОСОБИСТОСТІ СПІВАКА-ВИКОНАВЦЯ В УМОВАХ СУЧАСНОГО ОСВІТНЬОГО ПРОЦЕСУ
}

У статті розглядаються проблеми формування творчої особистості співака-виконавия 8 умовах сучасної університетської освіти та його готовності до творчої професійної діяльності. Розглядаються питання впровадження в практику нових перспективних шляхів творчої діяльності як педагога-вихователя, так $i$ студента. Доводиться, що метою підготовки студентів-вокалістів має стати не тільки підвищення рівня, а й модифікація змісту вокальної підготовки $i$ площини формування вокально-виконавської, мистецькотеоретичної та методичної компетентності. 
Всі ичі проблеми розглядаються крізь призму теорії та практики європейського вокального виховання, через дослідження умов самореалізації особистості, яка має необхідність створення умов для виявлення студентами власних музичних здібностей та творчого потениіалу, професійно-вокальних якостей.

Науково обтрунтувано необхідність формування творчої особистості співака-виконавия на основі вимог сучасних європейських вокальних методик. Найважливішим завданням підготовки майбутнього фахівия-вокаліста є його індивідуальний, особистий розвиток. Всі засоби виразності обов'язково повинні мати в своїй основі певну думку, певне внутрішнє почуття. Формування вокально-творчої особистості повинно супроводити буквально всі етапи постановки і розвитку голосу співака-виконавия в системі вищої університетської освіти, всі види роботи як студента, так і майбутнього співака-професіонала. Можливість якогось гармонійного $і$ художньо-доиільного розвитку співацького апарату без техніки вокально-творчого розвитку виключається.

Доводиться, щзо розвиток вокально-виконавської творчості включає в себе як розвиток техніки володіння голосовим апаратом, так $i$ психотехніку - техніку переживань. Визначається, що спеціаліст XXI cm. повинен бути висококваліфікованою особистістю, яка здатна до самостійності, ініціативності творчого мислення, вирішення проблем нестандартним шляхом.

Ключові слова: вокально-мистецька освіта, творчий потенціал, фахова підготовка, професійна діяльність, компетентність, самореалізація.

Розвиток вокально-мистецької освіти України на сучасному етапі розвитку музично-педагогічної науки актуалізується і модернізується під впливом соціального замовлення, яке орієнтує ії на виконання завдань підготовки фахівців нової формації з високим рівнем компетенції та професійно-фахової підготовки.

Проблема формування творчої особистості співака-виконавця в умовах сучасного освітнього процесу та його готовності до творчої професійної діяльності - одна найважливіших для вокально-педагогічної науки. Актуальність проблеми саме обумовлена завданням модернізації системи сучасної мистецької освіти України, що потребує впровадження у навчальний процес ефективних форм і методів навчання студентів.

Аналіз публікацій з даної проблеми показав, що різні аспекти розвитку творчого потенціалу студентів вищих навчальних закладів знайшли відображення в наукових працях В. Антонюк, Ю. Юцевича, М. Микиши, В. Голубєва, В. Морозова, Л. Дмітрієва та ін. Сучасна вища вокальна освіта має значні здобутки у галузі професійної підготовки студентів-вокалістів в процесі музично-виконавської діяльності. Але проблема формування саме творчої особистості співака-виконавця, як основи розвитку фахової підготовки студента-вокаліста в процесі підвищення якості підготовки майбутнього виконавця залишається достатньо актуальною.

Мистецька галузь професійної освіти, до головних завдань якої належить формування та розвиток творчого потенціалу особистості, потребує впровадження в практику нових перспективних шляхів творчої діяльності як педагога-вихователя так і студента. У вищих музичних навчальних закладах (зокрема у "інститутах мистецтв" Університетів), курс “Сольний спів" орієнтований на підготовку співака - виконавця всебічно розвинутого, здатного формувати художньо-естетичні смаки слухачів засобами вокального мистецтва. Сутність підготовки майбутніх співаків до професійної діяльності 
зводиться до високого рівня їхнього професіоналізму, що забезпечується формуванням вокально-технічних навичок з підготовленістю до виконання педагогічної діяльності 3 орієнтацією навчання на музичну профрілізацію (О. Олексюк). Ця думка підтверджує, що метою підготовки студентів-вокалістів має стати не тільки підвищення рівня, а й модифікація змісту вокальної підготовки і площини формування вокально-виконавської, мистецькотеоретичної та методичної компетентності. Тому компетентність студентавокаліста є незмінною умовою ставлення його як фахівця.

Отже, питання організації системи формування творчої особистості співака-виконавця ще не знайшло належного наукового обґрунтування, що і визначило завдання цього дослідження.

Мета і завдання статті - науково обґрунтувати необхідність фрормування творчої особистості співака-виконавця на основі вимог сучасних європейських вокальних методик.

Найважливішим завданням підготовки майбутнього фахівця-вокаліста $€$ його індивідуальний, особистий розвиток, який складається з:

1) технічного розвитку (бездоганне володіння музичним інструментом голосом);

2) розвитку та фрормуванню творчих можливостей особистості.

Для цього йому в процесі підготовки необхідно оволодіти інноваційними технологіями як інструментарієм вирішення завдань, що, “безумовно, збагатить методичне і практичне поле майстерності майбутнього фахівця, підвищить його компетентність і рівень професійної майстерності та відповідно сфрормує його творчу ціннісно-змістовну орієнтацію" [1, с. 77].

Сьогодні теорія і практика європейського вокального виховання до першочергових відносить дослідження умов самореалізації особистості, яка має враховувати необхідність створення умов для виявлення студентами власних музичних здібностей, творчого потенціалу, професійно-вокальних якостей.

У великому тлумачному словнику дається таке визначення поняття самореалізація. “Самореалізація - реалізація свого творчого людського потенціалу" [2, с. 31].

Видатний український педагог П. В.Голубєв надавав реалізації, формуванню творчого потенціалу студентів-вокалістів велике значення, виділяючи такі етапи в його розвитку:

- усвідомлення студентом своїх потенційних можливостей;

- визначення мети та програми дії її досягнення;

- побудову моделі діяльності;

- діяльність та самооцінка;

- формування висновків про перспективи свого я [3, с. 36].

Спираючись на ці висновки зміст підготовки майбутніх вокалістів у системі підготовки вищої музичної освіти повинен бути спрямованим на формування у студентів-вокалістів таких компонентів самореалізації:

- самовизначення - уміння поставити завдання і відповідно діяти;

- самореалізація - розвиток творчих здібностей (наукових, художніх, технічних);

- самореабілітація - наявність можливостей захистити себе культурними 
засобами у несприятливому оточенні [3, с. 37].

Самовизначення і самореалізація активно сприяють самоосвіті, розвитку творчих здібностей. Суттєвим елементом в цьому процесі виступає творча спрямованість, яка реалізується у прагненні до професійного самовдосконалення.

З першого року навчання у ВНЗ починається робота над виразністю співу і формуванням творчо-виконавських здібностей студентів. 3 розвитком і закріпленням технічних можливостей студентів поступово зростають і вимоги виконавського плану.

Цьому сприяє і низка музичних предметів (сольний спів - камерний клас оперний клас), яка, доповнюючи і поповнюючи один одного, сприяє вихованню майстра вокального мистецтва.

Вокально-виконавська творчість охоплює як техніку володіння голосовим апаратом, голосом, так і психотехніку - техніку переживання. Психотехніка - це комплекс технічних прийомів, пов'язаних з творчими переживаннями під час співу. Основним засобом впливу на слухача $є$ вокальне образно-дійове слово, яке сприяє розкриттю сценічного образу. Тому саме слову й змістові слід приділяти особливу увагу в процесі роботи над репертуаром, над твором, роллю.

Гранична виразність співу, формування у студентів вміння володіння дійовим вокально-образним словом, яке спирається на професійно досконалу вокальну техніку - ось та основна відправна точка в системі виховання творчої особистості студента. Робота ця складається з декількох етапів:

1) Формування вокально-технічних навичок, а по суті створення музичного інструменту - голосу співака. Це основне завдання предмету - "сольний спів", на якому технічно оснащується, формується діапазон, вільне, яскраве звучання, здобуваються навички виконавської майстерності, адже коли “співак непевний у своїх силах і можливостях, коли він відчуває, що голос його не досить еластичний, рівний, вільний і не зовсім кориться його волі, швидко втомлюється, коли, нарешті, йому щось заважає, щось його дратує - про формування вокально-творчого стану особистості не може бути й мови" [4, c. 69].

2) Коли студент набуває необхідного для співака - професіонала рівня вокальної техніки, питання виразності співу, творчого розвитку набирає домінуючого стану. Процес виховання творчої особистості розширюються. На занятті з "камерного класу" відбувається:

- знайомство, вивчення і всебічний аналіз камерних творів з навчального репертуару;

- вокальне читання і декламація тексту;

- координація технічних і творчих вимог.

Розвитку засобами виразності в процесі творчого формування особистості безумовно треба надавати великого значення і особливо старанно працювати над їх розвитком. Всі засоби виразності обов'язково повинні мати в своїй основі певну думку, певне внутрішнє почутя. Без цього темброве забарвлення звука буде фральшивим і непереконливим, міміка - гримасою а сценічний рух механічною дією робота. Керуючись таким постулатом, роботу над розвитком творчої виразності треба проводити тільки комплексно, пов'язуючи у вправах 
міміку й рух з емоційним забарвленням голосу, яскраве почуття, глибока думка самі мимоволі викликають певний вираз очей і обличчя, характерні рухи голови і тіла. Завдання студента полягає в тому, щоб відповідно посилити ці засоби. Матеріалом для таких вправ можуть бути спеціально підібрані з яскравими спеціальними станами.

Кожен зі студентів має свій характерний фрізичний тембр голосу.

Але в межах основного тембру він може надавати своєму голосу більш або менш яскравих відтінків: радості, горя, ніжності, суму, люті, злорадства, тобто користуватись палітрою емоціональних тембрів. Уміння володіти цим $€$ дуже впливовим засобом виразності і дуже збагачує виконання творів.

Найяскравішим етапом розвитку творчих здібностей студентів $€$ етап роботи в "оперному класі", в якому найбільш яскраво акумулюються всі попередньо виховані творчі можливості студента, його виконавські можливості.

Створення сценічного образу (оперної ролі) повинно спиратися на певну систему роботи:

1) знайомство з роллю,вивчення і всебічний аналіз опери (історичний, музичний, технічний);

2) процес "вживання в образ";

3) координація дії.

Під час розкриття художнього образу створенню будь-якої оперної ролі дуже допомагає магічне “якби" (запропоновані обставини К. Станіславського), що збуджують уяву студентів.

Аналізуючи виконавську практику видатних вокалістів, можна зробити висновок, що не існує будь-яких абсолютних прийомів майстерності, що були б придатні для кожного художника. Тим більш у мистецтві співу, адже в кожному випадку перед нами індивідуальний інструмент - людський голос зі своїм тембром, психікою, фрізичними можливостями. Тому можна сказати, що майстерність і сила впливу виконавця на слухачів залежить головним чином від індивідуального вміння виконавця, який користується своїми особливими засобами й можливостями Отже, формуючи творчі здібності кожного окремого студента, треба пам'ятати, що секрет його подальшого успіху не тільки у наявності природних виконавських даних, але і в їх свідомому врахуванні і всебічному розвитку.

Чітке визначення характеру виконавських можливостей студента (тип голосу, характер голосу, фізичний і психічний стан, зовнішній стан) $є$ одним 3 найважливіших завдань в процесі виховання співака-виконавця.

Могутнім засобом творчо-виконавських можливостей співаків - виконавців треба вважати спостережливість. Видатний український співак і педагог Михайло Мишуга писав “без розвиненої спостережливості, без вивчення життя не може бути створено жодного оперного образу".

Тому працюючи над розвитком творчо-виконавських можливостей кожного студента треба звертати увагу кожного з них на те, щоб пильно придивлялися до людей, підмічали особливості їх поведінки, характерні рухи, вислови, манери, знаходили в їх діях типове та індивідуальне. Спостерігали природу та ії явище, накопичували свої спостереження, аналізували і залишали в пам'яті 3 подальшим використанням під час виконання вокальних творів.

Розглядаючи процес формування творчої особистості, слід зауважити, що 
далеко не всі його складові, всі властивості які зумовлюють майстерну виразність співу, можна розвивати шляхом щоурочного тренажу. Якщо такі засоби творчої виразності як емоційний стан, міміка, сценічний рух цілком доцільно корегувати кожного уроку, то спостережливість, всебічний розвиток, творча уява потребують тонкого направляючого впливу викладача і кропіткої самостійної роботи учня.

Треба зауважити, що вміння перевтілюватись, тобто творчо підходити до створювання сценічного образу, як і вміння володіти голосом, не приходить само пособі. Цього досягають шляхом повсякденної, цілеспрямованої, наполегливої праці. Але це не означає, що заперечується вроджена здатність, талант, якому часом вже з перших кроків під силу те, чого інші не можуть здобути шляхом тривалого навчання, тренування. І все ж працювати щодня, систематично, не покладаючи рук - це доля тих, хто пов'язав своє життя 3 мистецтвом вокалу.

Висновок. Таким чином формування вокально-творчої особистості повинно супроводити буквально всі етапи постановки і розвитку голосу співакавиконавця в системі вищої університетської освіти, всі види роботи як студента, так і майбутнього співака-професіонала. Можливість якогось гармонійного і художньо-доцільного розвитку співацького апарату без техніки вокальнотворчого розвитку виключається. Втілення в життя вокально-виконавських творчих вмінь здійснюється майбутніми спеціалістами під час виконання творів на заліках, екзаменах, під час концертних виступів, оперних спектаклів, що передбачає пошук специфрічних засобів виразної передачі емоційно-образного змісту вокального твору, оперної ролі шляхом високої технічної досконалості.

\section{Використана література:}

1. Вербек-Свердстрем В. Школа раскрытия голоса; путь к катарсису в искусстве пения / пер. с нем. Фодоровой Н. Н. Москва : Evidentis, 2009. 224 с.

2. Великий тлумачний словник сучасної української мови / уклад. і голов. редактор В. Т. Бусел. Київ-Ірпінь ВТФ “Перун” 2002. ст. 31-36.

3. Голубєв П. “Советы молодым педагогам - вокалистам" ст. 36-37. Київ : Музична Україна, 1970.

4. Демиденко В., Головатий М. Самореалізація: сутність, становлення, розвиток. Педагогіка $i$ психологія. 2004. № 2(43). Ст. 31-36.

5. Микиша М. Практичні основи вокального мистецтва. Музична Украӥна. Київ, 1971. Ст. 88.

\section{References:}

[1] Verbek-Sverdstrem V. (2009). Shkola raskrytiya golosa; put k katarsisu v iskusstve peniya / per. s nem. Fodorovoj N. N. M oskva : Evidentis, $224 \mathrm{~s}$.

[2] Velykyi tlumachnyi slovnyk suchasnoi ukrainskoi movy / uklad. i holov. redaktor V. T. Busel. Kyiv-Irpin VTF "Perun" 2002. st. 31-36.

[3] Golubyev P. (1970). "Sovety molodym pedagogam - vokalistam" st. 36-37. K iyiv : M uzichna U krayina.

[4] Demydenko V., Holovatyi M. (2004). Samorealizatsiia: sutnist, stanovlennia, rozvytok. Pedahohika i psykholohiia. № 2(43). St. 31-36.

[5] M ykysha M. (1971). Praktychni osnovy vokalnoho mystetstva. Muzychna Ukraina. K yiv, St. 88.

МАКАРОВА Э. В., ЯКовЕНКо В.Г. Формирование творческой личности певцаисполнителя в условиях современного образовательного процесса.

В статье рассматриваются проблемы формирования творческой личности певиаисполнителя в условиях современной университетского образования, и его готовности $\kappa$ 
творческой профессиональной деятельности. Рассматриваются вопросы внедрения в практику новых перспективных путей творческой деятельности как педагога-воспитателя так и студента. Доказывается, что иелью подготовки студентов-вокалистов должно стать не только повышение уровня, но и модификачия содержания вокальной подготовки и плоскости формирования вокально исполнительской, художественно-теоретической $и$ методической компетентности.

Все эти проблемы рассматриваются через призму теории и практики европейского вокального воспитания, через исследование условий самореализации личности которая имеет необходимость создания условий для выявления студентами собственных музыкальных способностей и творческого потенциала, профессионально вокальных качеств.

Научно обоснована необходимость формирования творческой личности певияисполнителя на основе требований современных европейских вокальных методик. Важнейтей задачей подготовки будущего специалиста-вокалиста является его индивидуальное, личностное развитие. Все средства выразительности обязательно должны иметь в своей основе определенную мысль, определенное внутреннее чувство. Формирование вокальнотворческой личности должно сопровождать буквально все этапь постановки и развития голоса певиа-исполнителя в системе высшего университетского образования, все виды работы как студента, так и будущего певиа-профессионала. Возможность какого-то гармоничного и художественно-целесообразного развития певческого аппарата без техники вокальнотворческого развития исключается.

Доказывается, что развитие вокально исполнительского творчества включает в себя как развитие техники владения голосовым аппаратом, так и психотехнику - технику переживаний. Определяется, что специиалист ХХІ в. должен быть высококвалифицированным личностью, которая способна к самостоятельности, инициативности творческого мьлиления, решения проблем нестандартным путем.

Ключевые слова: вокально-художественное образование, творческий потенцииал, профессиональная подготовка, профессиональная деятельность, компетентность, самореализация.

Makarova E. V., YAKOVEnKo V.G. Formation of the creative personality of the singerperformer in the conditions of the modern educational process.

The article deals with the problems of forming the creative personality of the singer - the performer in the conditions of modern univer sity education, and his readiness for creative professional activity. The questions of introduction into practice of new perspective ways of creative activity as a teacher-educator and student are considered. It turns out that the purpose of training students-vocalists should be not only raising the level, but also modification of the content of vocal training and the formation of vocal-performing, artistic-theor etical and methodological competence.

All these problems are considered through the prism of the theory and practice of European vocal education, through studying the conditions of self-realization of the individual who has the need to create conditions for the students to identify their own musical abilities and creative potential, vocational qualities.

Scientifically substantiated the need for the formation of the creative personality of the singer based on the requirements of modern E uropean vocal techniques. The most important task of training a future specialist vocalist is his individual, personal development. All means of expression must necessarily be based on a certain thought, a certain inner feeling. The formation of a vocal and creative personality should accompany literally all stages of the production and development of the singer's voice in the system of higher university education, all types of work of both the student and the future professional singer. The possibility of some kind of harmonious and artistically expedient development of the singing apparatus without the technique of vocal and creative development is excluded.

It turns out that the development of vocal-performing arts includes both the development of the technology of possession of the vocal apparatus, and psycho-technology - the technique of emotions. It 
is determined that the specialist xx1 Art. should be a highly skilled person capable of autonomy, initiative of creative thinking, and solving problems in a non-standard way.

Keywords: vocal-artistic education, creative potential, professional training, professional activity, competence, self-realization.

DOI: https://doi.org/10.31392/NZ-npu-142.2019.17

УДК 378.091

Малежик П. М.

\section{ПЕДАГОГІЧНІ АСПЕКТИ РОЗВИТКУ ІНТЕЛЕКТУАЛЬНИХ УМІНЬ МАЙБУТНІХ ФАХІВЦІВ 3 КОМП'ЮТЕРНИХ НАУК ПІД ЧАС ВИВЧЕННЯ ТЕХНІЧНИХ ДИСЦИПЛІН}

У статті розглянуто та проаналізовано науково-педагогічні джерела, щзо розкривають сутнісні аспекти технічної складової професійної підготовки майбутніх фахівиів з інформаційних технологій до професійної діяльності. Визначено та обтрунтовано педагогічні умови, необхідні для забезпечення розвитку інтелектуальних умінь майбутніх IT-фахівиів під час навчання технічних дисциплін. На основі аналізу джерел $з$ питань розвитку інтелектуальних вмінь студентів визначено завдання дослідження їх структури. Вказано на важливість розвитку інтелектуальних умінь в студента, щуо є невід'ємною складовою процесу формування професійних компетентностей майбутнього фахівия.

Визначенно $і$ обтрунтувано педагогічні умови та вибір засобів, щзо забезпечують формування структури інтелектуальних умінь майбутніх фахівців IT-галузі. Основою інтелектуальних умінь є система інтелектуальних дій, що складаються з логічних мисленнєвих операиій (прийомів): аналіз, синтез, виділення головного, порівняння, узагальнення, систематизація, конкретизація, абстрагування, доведення, моделювання, прогнозування. Інтелектуальні вміння не даються від народження в готовому вигляді, вони є одночасно $i$ результатом, $і$ умовою розвитку, щзо здійснюється в прочесі навчання $i$ виховання, під час взаємодї з навколишнім середовищем.

Нарощування кожного інтелектуального уміння у процесі вивчення технічних дисииплін можна реалізувати шляхом урізноманітнення вправ, ситуативних завдань, проектів. Психологічні механізми інтелектуальної поведінки формуються, а структура інтелекту емпірично залежить від процесів його формування. Чинником, який визначає успіх людини в тій або іншій складній реальній діяльності, є не рівень розвитку тих або інших інтелектуальних механізмів, які виявляються при виконанні тестів інтелекту, а інтелектуальний потенціал, який обумовлює можливість формування нових механізмів.

Ключові слова: технічна підготовка, педагогічні умови, інтелектуальні уміння, структура інтелектуальних умінь, майбутній фахівець з комп'ютерних наук.

Серед пріоритетних напрямів державної політики України є розвиток інформаційного суспільства та широке впровадження інформаційних технологій в усі галузі життєдіяльності людини. В зв'язку з цим, виникає потреба у висококваліфікованих IT-фрахівцях, які здатні до засвоєння, генерування та практичної реалізації нових наукових ідей, розроблення та використання сучасних технічних пристроїв [1]. Отже, на сучасному етапі 